\title{
Inter-Asian Corridor of Connectivity (2): West Asia - China, the Arabian Peninsula and Turkey
}

In June 2016, I visited the trading office in Yiwu of Abdul Rahman on a hot and humid afternoon. Abdul Rahman is an ethnically Turkmen trader from Afghanistan who operates a trade and transport business largely serving visiting businessmen and women from the post-Soviet state of Turkmenistan. ${ }^{1} \mathrm{He}$ has never visited Turkmenistan, yet his Turkmen ethnicity means that he is able to speak the Turkmen language; doing so enables him to work with traders from the country with ease. Brought up in a predominantly Turkmen village in north-western Afghanistan, he left the country with his family as a teenager, initially moving to the city of Peshawar in north-west Pakistan and occasionally spending time working in Jeddah, Saudi Arabia - something he like many others in this and other communities do by acquiring and then overstaying pilgrimage visas. ${ }^{2}$ As was the case with hundreds of Afghan Turkmen families, in Pakistan the family established a business trading in carpets handwoven by Afghan refugees. Later in the 2000s, Abdul Rahman left Pakistan with his family. They joined several Afghan Turkmen families in the Gulf city of Sharjah, opening an office that provided trading and transport services to visiting merchants from Turkmenistan. In the context of a steep decline in this trade, resulting from changing import duties in Turkmenistan, Abdul Rahman relocated his commercial activities to Yiwu. Rising costs in the UAE, alongside the inability of foreigners based in the country to become naturalised citizens, led him to move his wife

${ }^{1}$ The category 'Turkmen' is used in the context of premodern history to refer to various Turkic groups that had converted to Islam and lived in particular steppe areas of Central Asia. In the context of Russian imperial and Soviet nationalities policy, 'Turkmen' was increasingly used as an ethnolinguistic identity marker. Turkmens constitute one of Afghanistan's smaller ethnolinguistic communities, numbering around two million. Turkmens have traditionally inhabited arid regions along the country's northern and western borders. The community comprises émigrés from Russian Turkestan as well as communities that had settled on the south bank of the Oxus historically. Today, they are an increasingly important aspect of the country's urban populations. See Bregel 2009. On the notion of the modern category of Turkmen, see Edgar 2006. On the political and economic activities of Turkmen in the context of Iran, the Central Asian Khanates and Russian imperial expansion, see Eden 2018.

${ }^{2}$ Cf. Jeong 2019. 
and children to Istanbul. He secured residency permits for his family by cultivating relationships with the relevant authorities and renting an apartment in Zeytinburnu - a neighbourhood in which several members of his community (including one of his elder brothers) lived. As we chatted in Yiwu about trade and family life, Abdul Rahman pulled a partially consumed bottle of Chinese red wine from a draw in his desk. He had been entertaining a Chinese woman in his flat the night before, he told me, but, being Muslim, he did not drink - 'take it, and finish it', he instructed me.

Chapter 2 demonstrated that Afghan networks are playing an important role in forging transregional connections across Eurasia. Afghans active in the formerly Soviet parts of Eurasia publicly perform their ability to thrive in the secular environments they inhabit. They emphasise their skills in adapting to cultural contexts markedly different from their own. For these traders, demonstrating political belonging to Afghanistan and the nation states in which they live is an important aspect of their identities and something they regularly do through their participation in 'Afghan' diaspora organisations and displays of loyalty and allegiance to their adopted homelands. ${ }^{3}$

This chapter explores a second key human-commercial corridor that acts as a channel for a specific trading network. It illuminates the activities of traders who identify with adjacent regions of Afghanistan and Central Asia. These traders currently live and work, however, in two of Muslim Asia's historic and most significant religious, commercial and political centres: Istanbul and Jeddah. Going beyond the tendency in much scholarly work to fixate on the East-West connectivity of the 'Silk Road', the chapter explores these networks in relationship to the geographical scale of West Asia. Unlike 'the Middle East' - which posits the existence of a distinct yet liminal cultural region that is neither Asia nor Europe 'West Asia' points towards a geographical scale that is defined by specific characteristics and dynamics but that is also inherently part of Asia more generally. In particular, West Asia helps to illuminate the simultaneous significance of dense North-South and East-West connections that collectively enable the interpenetration of multiple parts of Asia - these connections tend to be overlooked in the scholarship, which often focuses either on Eurasia or the dynamics of the Middle East. ${ }^{4}$ The distinctive nature of the networks described in this chapter is also an important reminder of diversity within the Eurasian arena as a whole and of the dangers of overly unitary attempts to conceptualise it. Afghan merchants of backgrounds very different from those discussed in Chapter 2 bring

${ }^{3}$ Aydin 2017. ${ }^{4}$ See Marsden and Mostowlansky 2019. 
together East Asia, the Arabian Peninsula and Turkey as a triangle. The trading networks involved in mediating these connections, furthermore, act pragmatically within the nation state system at the same time as cultivating collective identities that do not revolve around onedimensional belonging to Afghanistan.

The traders discussed in what follows identify as hailing from a range of late modern political entities located in Central Asia, especially the Emirate of Bukhara. Russian imperial projects weakened the structures of these Central Asian polities from the mid-nineteenth century onwards. Russian Turkestan was established in 1867 and expanded until 1889, resulting in the Emirate of Bukhara and the Khanates of Koqand and Khiva being reduced to Russian protectorates. In the context of the Bolshevik Revolution and Soviet rule in Central Asia, these protectorates disintegrated further: eventually, they were fully incorporated into the region's newly created Soviet republics. Until the middle of the nineteenth century, mobile people from the region - including merchants, itinerants and pilgrims - continued to play a critical role in connecting Central Asia to other parts of Asia, as well as to Europe. ${ }^{5}$ However, by the 1920s, Central Asia had effectively been isolated from such long-distance and cross-cultural commercial dynamics. Many historians and anthropologists have explored the effects that Central Asia's isolation from the wider region had on the nature of life in its cities and villages, the role played by Islamic authorities, knowledge and institutions in its societies and its perception as a distinct region by outsider observers. ${ }^{6}$ As Lâle Can notes, the 'afterlife' of Central Asian 'transimperial mobility and travel' in the years following the Bolshevik Revolution is less widely told. ${ }^{7}$

As the case of Abdul Rahman indicates, many of the traders whose lives are explored in this chapter invest great emphasis on the importance of Islamic teachings and prescriptions to their personal and collective identities. In contrast to the traders discussed in Chapter 2, they also reflect openly on the ways in which the geographical parameters of the worlds they inhabit reflect their considerations of the type of context in which leading a good Muslim life is possible. At the same time, however, Islam does not dictate the identities and political affiliations of Central Asia's émigré traders. Instead, traders working in this network pursue various strategies to secure access to citizenship and legal residency of the countries in which they live, including those that emphasise their distinctive ethnolinguistic and regional identities, as well as their commitment to

${ }^{5}$ Levi 2020, Levi 2017 and Can 2020.

${ }^{6}$ Humphrey, Skrvskaja and Marsden 2009, Khalid 2007, Megoran, Nick and John Heathershaw 2011, Sahadeo 2011a.

${ }^{7}$ Can 2020: 172 . 
being Muslim and adherence to the Islamic tradition. That these traders are the descendants of historic émigrés from a political entity that no longer exists also occupies a powerful element of their selfunderstandings, the ways in which they present themselves to the wider world and their modes of building community. As we shall see, traders refer to themselves using names that denote the regions of Central Asia from which their forefathers hailed; they also brand the products in which they deal by referencing Central Asia's historic geography.

This chapter explores the activities and networks of merchants and artisans who fled from Central Asia to Afghanistan in the 1920s and 1930s, charting the ways in which these people deployed their commercial skills not only in Afghanistan but also across many contexts that straddled geopolitical divisions over the course of the century that followed. It documents and analyses the networks and nodes that shape the dynamics of this commercial corridor linking China and West Asia. An especially important aspect of the dynamics of these nodes emerges from the social institutions that Central Asian émigré merchants are active in establishing along this corridor, so I will also investigate the relationship of such institutions to their identities and to shifting geopolitical contexts and initiatives.

Religion influences these traders' identity, agency and patterns of mobility, yet not in a one-dimensional or totalising way. Rather, the members of this mobile society pursue multiple strategies - including emphasising various aspects of their religious, regional and ethnic identities - to maintain connections with their site of dispersal and build connections with their new homelands as well as the third spaces in which they have lived in the past. Given their historic commitment to trade, it is not surprising that such strategies also seek to maximise their ability to maintain and expand their business activities. Moreover, exploring such networks in detail provides an opportunity to reflect on the types of cultural and ideological resources deployed by actors who work within a world informed by Islam that is nevertheless forged in the midst of competing geopolitical projects.

\section{Turkestani Socks and Bukhari Rice: The Making of an Ethnographic Moment}

Before embarking on a detailed discussion of the Central Asian émigré merchants who are the focus of this chapter, let me explain how I came to recognise the particular significance of the West Asian corridor within the wider Eurasian arena during the course of my fieldwork. Doing so adds depth to the argument made in Chapter 1 about the intertwined nature of 
fieldwork and analysis, as well as illustrating the historically layered and dynamic nature of the trading networks studied in this book.

In November 2017, I visited the al-Asif Square apartment blocks in Karachi's Sohrab Goth neighbourhood and encountered a street vendor selling a pair of socks that piqued my interest. In the context of the conflict between mujahidin fighters and the Soviet and Afghan armies in the 1980s, Sohrab Goth had earned a reputation across South Asia as being a hotbed of religious militancy, gunrunning and drug smuggling. ${ }^{8}$ The reason for my visit to Sohrab Goth, however, was to meet Central Asian émigrés. In the late 1970s, the neighbourhood saw the arrival of thousands of refugees from northern Afghanistan, many of whom were the descendants of Central Asian émigré families; during my visit to Karachi, muhajirs also told me that after arriving in Karachi they had met Turkicspeaking families that had resided in the city since fleeing Turkestan in the 1930s. It was in this context that I was delighted to come across a pair of socks for sale in a makeshift and moveable store - the merchant who had commissioned their manufacture in China had branded the socks 'Turkestani'.

My interest in the Turkestani-branded socks in Karachi had arisen as a result of interactions with Central Asian émigré merchants in Yiwu. On a wet March evening in 2016, I had bumped into two traders in their midforties from Afghanistan. The night market was a space in Yiwu that I visited most evenings while based in the city. As well as frequenting the many cafés and restaurants in this part of the city, traders visiting Yiwu on short visits tend to while away their evenings by walking around the market and checking out the products for sale. Traders sometimes also visited the night market with the aim of finding new products in which to deal. For the most part, though, such visits offered a time to relax with friends and to purchase gifts for their families - I found traders to be more approachable during such moments of relaxation than during the day. I initially assumed the two men had come to the city from Afghanistan, and because of the clothing they wore that they were from the northern city of Mazar-e Sharif. Many traders visit Yiwu to send products to northern Afghanistan using overland transport routes that pass through Kazakhstan and Uzbekistan. It was a surprise, then, when they told me that they had visited China not from Afghanistan but Saudi Arabia, where they were based in the Red Sea port city of Jeddah. After chatting about the political dynamics of northern Afghanistan, they gave me their business cards before heading back to their hotel.

${ }^{8}$ See Hassan 1987. 
For the remainder of the time I spent in Yiwu, I regularly enquired about the Afghan community in Saudi Arabia and their ties to China in general and Yiwu in particular. I was told about a street in Jeddah called 'the Bukhariyya', or, in Farsi, 'street of the Bukharans' (kucha-ye bukhariha). An Afghan trader based in Yiwu who was in his late fifties told me that as a young man he had stayed in Jeddah for several years in the 1970s. While having travelled to Saudi Arabia on a government scholarship, his involvement in Afghanistan in an Islamist political organisation meant that other members of the party advised him not to return regularly to his home. Indeed, after winning a scholarship to study in the United States, Afghan embassy officials in Saudi Arabia had told him he must return to Kabul to extend his passport, something that eventually resulted in him being jailed, and, in later years, playing an active role in the 'jihad' against the Red Army. He had consequently sought employment in Jeddah, eventually securing a job as an accountant in a restaurant owned by an ethically Turkmen man from northern Afghanistan. In addition to owning a restaurant, his employer also imported spare parts to Saudi Arabia from Japan and South Korea - it was while working as an accountant that the trader had first learned how to deal in commodities procured in East Asia. I was able to glean insights about the Afghan community in Saudi Arabia and Jeddah in particular through conversations with such traders; I doubted that I would ever be able to travel to Saudi Arabia to explore the forms of trade important in the Bukhariyya Street itself. Rather abruptly, however, I heard in October 2016 that I had been appointed a Visiting Fellow at the King Faisal Research and Islamic Studies Centre in Riyadh, an appointment that would allow me to visit Jeddah and meet traders working there who were from Afghanistan.

Within two hours of landing in Jeddah after the short flight from Riyadh, I had already bumped into the men I had met on that spring night in Yiwu. They were now dressed in Arab robes and showed me the shops they traded from in historic Jeddah. Both of the men sold trainers that they imported to Saudi Arabia from Guangzhou and Yiwu. Over the following three weeks I stayed in Jeddah, I had many meetings and encounters with traders I had met in both China and Turkey.

Much of my time was spent making visits to 'Bukhariyya Street', about which traders in Yiwu had told me so much. The Bukhariyya Street is actually a neighbourhood comprising two commercial streets. The neighbourhood's narrow alleys are bustling with activity: children run around from house to house, and men make their way to and from the many mosques located in the area, as well as the local bakery. Men from northern Afghanistan, especially those who identify as ethnically Uzbek or Turkmen, staff the shops on both of the main streets that run through 
the area. There are also Farsi-speaking 'Tajiks' from eastern and northern Afghanistan; two of these families also told me that they were the descendants of émigrés who had left eastern regions of the Emirate of Bukhara in the $1920 \mathrm{~s}^{9}{ }^{9}$ The businesses on one of the streets relate predominantly to the restaurant trade, a sector of the Saudi Arabian economy within which people from northern Afghanistan are very active. ${ }^{10}$ In this street, Afghans sell the type of large aluminium cooking pot (deg) in which the region's famous rice dish - palaw - is cooked; 'Bukharan' Afghans who live in the nearby city of Taif mostly craft these pots from steel. The businesses on the other street in the Bukhariyya Street centre largely deal in the sale of carpets, prayer mats, blankets and furniture. Most traders in this street deal in goods imported from China or Turkey. A couple of shops on the street also sell handwoven carpets from Afghanistan, Iran, China, Pakistan and the Caucasus - customers visiting these carpet shops are mostly wealthy Saudis.

\section{West Asia}

Spending time in the shops of Bukhariyya enabled me to meet young men who while resident in Jeddah had spent much of their adult lives in Chinese cities (mostly Yiwu and Guangzhou) and spoke fluent Cantonese or Mandarin in addition to Persian and Arabic. During my conversations with these men and their families in Jeddah and Riyadh, I learned of their family backgrounds in Afghanistan, the processes through which they had migrated from Afghanistan to Pakistan and then to Saudi Arabia, their modes of making a living, as well as their relations with other communities in these cities.

Most traders of an Afghan background working in these contexts claim descent from families who lived in the emirates of Central Asia and who emigrated 'across the Oxus river', seeking refuge in Afghanistan in the 1920s. This movement occurred in the context of the Bolshevik persecution of notable and wealthy families and was mostly to towns and villages in the north-west and north-east of Afghanistan. ${ }^{11}$ The provinces of Afghanistan in which these families resettled are all close to the border with the former Soviet republics of Turkmenistan, Uzbekistan and Tajikistan. Until the consolidation of the Afghan state by Emir Abdur Rahman Khan in the late nineteenth century, ${ }^{12}$ this region had been made up of various dynasties involved in tributary relationships with the

\footnotetext{
${ }^{9}$ For a rich ethnographic account of this region - now a part of Tajikistan - see IbañezTirado 2013.

${ }^{10}$ See Chapter 7. $\quad{ }^{11}$ Khalid 2007. $\quad{ }^{12}$ Edwards 1996.
} 
Emirate of Bukhara and with polities to the east and the south. ${ }^{13}$ After the delineation of an international boundary by the Afghan Boundary Commission in the mid-nineteenth century, the region was officially designated as 'Afghan Turkestan'. ${ }^{14}$ Most of the traders making up this network are from families that moved permanently to Afghan Turkestan in the late 1920s in the wake of the Stalinist purges of notables, wealthy peasants and religious authorities in Central Asia. From the 1920s, there was a progressive strengthening of the border between Soviet Central Asia's new republics and Afghanistan. ${ }^{15}$ Many of my interlocutors have told me that their families were merchants and artisans in Bukhara and were able to continue their activities in this field in Afghanistan. Other families turned to trade after leaving their homes in Central Asia. ${ }^{16}$ Many such families often remark that status hierarchies that had been important in Central Asia were upturned and recast in Afghanistan: slaves (ghulam) became successful traders, for example, eventually accruing more capital than historic merchants, only some of whom were able to adapt to the new circumstances.

The commercial acumen of these families reflects the early modern economic dynamics of Bukhara. The city of Bukhara was a historic site of transregional Asian trade that involved merchants from the region travelling to Iran, Muscovy, Siberia, China and India. While much scholarship has taken for granted that Central Asia became isolated from the global economy in the context of the development from the eighteenth century onwards of sea trade by European imperial powers, recent work contests this approach and has brought attention to 'multivectoral' sedentary and nomadic networks that 'linked Central Asia with its neighbours on the Eurasian peripheries'. ${ }^{17}$ Audrey Burton has documented the wide range of contexts that were important to the activities of Bukharan merchants between 1558 and $1718 .^{18}$ Merchants from Bukhara made trading sorties across this period to Iran, Muscovy, Siberia, China and India. During these sorties, they transported goods from Bukhara for sale (especially the region's high-quality cotton materials and furs largely made from sheepskin) and purchased goods for sale either in Bukhara or other regions in which Bukharan merchants were active: rhubarb purchased in China and Siberia was thus sold in Iran, where it was regarded as an essential medicinal ingredient. Not all Bukharan merchants operated in this

\footnotetext{
${ }^{13}$ Lee 1996. $\quad{ }^{14}$ Fuoli 2017. $\quad{ }^{15}$ Dagyeli 2017 and Marsden and Hopkins 2012.

${ }_{17}^{16}$ Jalallar 2011.

17 Levi 2020: 37-35. Bukhara also exerted transregional influence until the middle of the nineteenth century as a result of its status as a centre of Persianate education and learning, see: Pickett 2020.

${ }^{18}$ Burton 1993.
} 
mobile manner. Burton also identifies the role played by individual merchants who were permanently settled outside of the emirate in the activities of merchants based within it. In Siberia, for example, settled Bukharan merchants owned land and ran businesses. ${ }^{19}$ In addition to dealing with far-away people and their rulers, Bukhara's merchants also engaged in close trading relations with the communities surrounding the urban centres in which they lived: they collected fur and carpets from Turkmen tribes and provided Bukhara's elite with fermented mare's milk.

The nineteenth century saw the progressive incorporation of the Emirate of Bukhara within the Russian Empire and, during the twentieth century, the Soviet Union, which led to the demise of the city's and the wider region's significance for inter-Asian commerce and connectivity. ${ }^{20}$ In the wake of the creation of the Soviet Union, however, a proportion of Bukhara's commercial community left Central Asia, moving into presentday Iran, Afghanistan, Chinese Turkestan and India. After leaving Central Asia, some of the Central Asian émigrés settled in the contexts to which they had initially moved: northern Afghanistan continues to be home to substantial and settled communities of Central Asian émigrés. ${ }^{21}$ A smaller number of émigré families in a position to do so, however, migrated out of these neighbouring regions, most frequently to Jeddah and the holy cities of the Hejaz: Mecca and Medina. ${ }^{22}$ In the Hejaz, there were pre-existing communities of Central Asians who had initially travelled to the territories of modern-day Saudi Arabia with the intention of making the haji pilgrimage but later stayed on either because they lacked the funds to return home or sought to benefit from the opportunities offered by acting as middlemen between Arab guides and Central Asian pilgrims. ${ }^{23}$ In later years, these communities were joined by émigrés from Chinese Turkestan who either fled after the collapse of the Turkestan state in 1949 or found themselves conducting pilgrimage in Arabia as the events in China unfolded. ${ }^{24}$

Bukharan émigrés who remained in northern Afghanistan adapted to a new set of circumstances in Afghan Turkestan. After moving to Afghanistan, the trade of lamb pelt (karakul) continued to be of importance to members of the community, but they also became active in related commercial fields, such as the sale of meat and skins. As I explore in Chapter 5, northern Afghanistan's fur trade had also attracted Farsispeaking Afghan Jewish traders and financiers based in the cities of

\footnotetext{
${ }^{19}$ Monahan 2015. $\quad{ }^{20}$ Humphrey, Skvirskaya and Marsden 2009. $\quad{ }^{21}$ Shahrani 2001.

22 On Jeddah as a site of convivial cosmopolitan diversity, see Freitag 2020.

${ }^{23}$ Balci 2003 and Kane 2015. ${ }^{24}$ Thum and Kashgary 2020.
} 
Kabul and Herat, as well as Bukharan Jews who had fled the violence that affected their lives and commercial activities in Bukhara, Samarqand and Tashkent from 1918 onwards. Central Asian traders today intermittently suggest that some members of their community are 'originally' (asl) Bukharan Jews who converted to Islam only after moving to Afghanistan from the Soviet Union. Indeed, wealthy traders identifying as 'Bukharan' and currently based in Saudi Arabia are widely said by their fellow Central Asian émigrés to be Farsi-speaking Jewish converts to Islam.

The modern trade in 'Bukharan' carpets to European and American markets stretches back to the eighteenth century. ${ }^{25}$ From the 1960 s to the present day, some of Afghanistan's most well-known merchants came from families that had crossed the Amu Darya and migrated to Afghanistan in the late 1920s and 1930s. The role that such merchants played in innovating the production and distribution of carpets raised their social status, both within and beyond the country. They established small factories in northern Afghanistan that employed men and children to weave cheap carpets specifically for the 'Western market'. Émigré merchants in Afghanistan also opened transport companies that connected the cities of northern Afghanistan to Pakistan, Iran, the Arabian Peninsula, Turkey and Germany and created international business networks, most especially in the global centres of the carpet trade, Hamburg and Istanbul. ${ }^{26} \mathrm{~A}$ merchant in his mid-seventies who runs a carpet business in Jeddah told me that he had initially travelled in the 1960s and 1970 s to Saudi Arabia by road from Afghanistan. The trader made money en route by selling Indian-made jewellery in Iran and on arriving in Mecca sold Afghan carpets to Yemenis; on his return, he told me, he sold abayas (gowns worn by women) that he bought in Kuwait to Iranians in Tehran. In the late 1970s, traders used these routes to move themselves and their families out of Afghanistan on a permanent basis. During the twentieth century, successful Central Asian merchant families also became close to Afghanistan's urban elite: they sometimes intermarried with powerful Afghan families and were appointed to high-level government positions, even if they continued to be widely referred to as having come to the country from 'the other side of the river' (pan-e darya; ubar $e$ darya). ${ }^{27}$ A handful of such elite families left Afghanistan for Saudi Arabia, Europe and the United States after the 1973 coup d'état that resulted in the overthrow of Afghanistan's monarchy. In the United States, for example, several families of this background settled in Brooklyn and New Jersey.

\footnotetext{
${ }^{25}$ Spooner 1986. $\quad{ }^{26}$ Ibid.: 216-17. $\quad{ }^{27}$ Nasiri and Khalili 2013 and Jalallar 2011.
} 
After the 1979 Soviet invasion of Afghanistan, thousands of émigré families who had continued to live in Afghanistan fled to Pakistan, fearing the confiscation of their lands by the communist regime in Kabul. Community elders often supported various anti-Soviet mujahidin organisations, yet many families migrated in order to avoid their children being conscripted into the Afghan army or the ranks of the mujahidin. ${ }^{28}$ In Pakistan, merchant families continued to be active in the manufacture of and trade in the Central Asian carpet industries, while those from village backgrounds regularly wove carpets on a commission basis. In the late 1980s, hundreds of these families moved from Pakistan to Jeddah in Saudi Arabia: as we have seen, Central Asians had lived in Jeddah's Bukhariyya neighbourhood since at least the 1850 s, and a later flow of Central Asians had settled in the city and the Hejaz region in the 1920s and 1930s.

The Central Asian émigrés who arrived in Jeddah in the 1980s rapidly established themselves there as well as in Mecca and Medina. They initially filled niches in the economy that earlier waves of Central Asian migrants had vacated, especially restaurants selling the 'national dish' of Saudi Arabia, ruz al-bukhari-a type of social institution I explore in detail in Chapter 7. In the following decades, Afghanistan's Saudi-based Central Asian émigrés also became active in the import from Turkey and subsequently China of machine-made prayer carpets and cheap ready-made clothing, both items purchased by hajjis and overseas labourers as gifts to take to their home countries.

\section{The Strategic and Cultural Dimensions of Mobile Citizenship in West Asia}

In Chapter 2, we saw that Afghan community associations played a critical role in brokering relationships between networks and the state and its officials - relationships that have allowed traders to establish nodes that act as anchor points for their communities in formerly Soviet settings. Such relationships also facilitated the access of Afghans to visas, residency permits and citizenship of the countries in which they worked.

I now address issues relating to citizenship and residency rights that are important to the experiences and activities of Central Asian émigré traders working in the West Asian corridor of connectivity. The material presented below points to concerns that overlap with those in the chapter on the Eurasian corridor, especially in terms of the role played by formally recognised associations in brokering between the state and Afghan traders

${ }^{28}$ Shalinsky 1993 and Shahrani 1984. 
and migrants. There are, however, also important contrasts between the experiences of traders working in these two corridors of connectivity. On the one hand, these reflect the different approaches to citizenship taken by the countries in which they live and work. It is widely known that over the past half-century Saudi Arabia and the Gulf states more generally have come to manage immigration through specific visa and residency permit regimes rather than offering the possibility of integration through citizenship. ${ }^{29}$ A sophisticated body of scholarship has argued that the absence of states conferring formal citizenship rights on immigrants has resulted in overseas communities making claims to citizenship at different levels. Anthropologist of the UAE Neha Vora, for example, has developed the term 'consumptive citizenship' to describe the ways in which immigrants regard long-term economic contributions to the societies in which they live as acting as the basis of their citizenship claims. Such a wider understanding is helpful for interpreting the dynamics of stable communities with relatively straightforward access to formal citizenship in their countries of 'origin'. ${ }^{30}$

Afghanistan's Central Asian émigrés identify with territories and political structures that no longer exist: they trace their 'origins' to a 'somewhen' as much as a 'somewhere'. ${ }^{31}$ As Diana Ibañez-Tirado has argued, scholars of such mobile societies must recognise how mobile people not only switch identifications, identities and affiliations as they move across different contexts but also do so in relation to 'who they have become in different times'. Deploying this dynamic understanding of identity reveals 'different understandings of space and time beyond the authoritative master narratives of history and the existing geographical categories that pinpoint migrants to a specific place of origin, and thus to established patterns of mobility and immobility, as well as fixed legal categories'. ${ }^{32}$

Most if not all of the Central Asian émigrés I am concerned with in this chapter hold Afghan citizenship as a result of their families having lived in the country for several decades. At the same time, many of the Central Asian émigré Afghan nationality-holding traders based in West Asia especially those living in the Arabian Peninsula and Turkey - have not been resident in Afghanistan for over forty years. Most left Afghanistan as children or young adults. They were subsequently educated outside the country and raised their families in a range of settings across West Asia. As a result, the traders discussed in this chapter widely think of themselves as being 'double émigrés': they are exiles from now non-existent Central Asian polities and also from the space in which their families initially

${ }^{29}$ Fargues 2011. $\quad{ }^{30}$ Vora 2013. $\quad{ }^{31}$ Da Col 2007. $\quad{ }^{32}$ Ibañez-Tirado 2018 b. 
sought refuge, Afghanistan. Regardless of whether they have access to capital or not, they inhabit an inherently precarious position in a world dominated by nation states. The precariousness they live with and through is rendered yet more complex by the citizenship policies of the countries in which these traders currently live: few if any of the traders belonging to this generation of émigré migrant to West Asia have earned citizenship rights in either Saudi Arabia or the UAE.

The influence of this specific context is visible in two interconnected ways in the material that follows. First, it is normal to think of trading networks and diasporas as sharing a single site or moment of dispersion. As we shall see, the identities of Central Asian émigré traders are closely intermeshed with transforming geopolitical initiatives and circumstances: they identify their backgrounds, identities and collective histories in changing ways according to the circumstances in which they find themselves and do so as much in relation to a time as a place of dispersal. Second, the precarious citizenship of most if not all traders who identify as being Afghan Central Asian émigrés is visible in these traders' pursuit of multiple strategies to secure residency and - in some instances - citizenship rights in the settings across which they work. In some contexts, they develop a 'strategic' approach to citizenship in order to address their vulnerable position; ${ }^{33}$ in other contexts they make claims to citizenship that resembles those anthropologists refer to as 'cultural citizenship' that is, claims based on cultural and historic connections to the host society which are regarded as being of value in that they confirm rights, representation and recognition. ${ }^{34}$

\section{Citizenship Dilemmas among Saudi Arabia's Central Asian Émigrés}

The central issue facing Afghan Central Asian émigrés living in Saudi Arabia is their citizenship status. Most of the émigrés from Central Asia who arrived in the Hejaz in the 1920s eventually secured citizenship in the Kingdom of Saudi Arabia and established themselves politically and economically there. ${ }^{35}$ Yet those who settled from the 1970 s onwards have not been awarded such documents and the rights they confer on their holders. Instead, these later double-émigrés are dependent on the granting of visa extensions by the kingdom and on applications for residency documents. As a result, the children and grandchildren of families that moved to Saudi Arabia in the 1970s continue to be legally regarded as 'foreigners' (ajnabi) by the country's government. Their ability to

33 Gardner 2008. $\quad{ }^{34}$ Ong 1996. $\quad{ }^{35}$ Balci 2003. 
maintain business interests and family lives in the country is entirely dependent on the dynamics of Saudi immigration policy. This situation is rendered even more complex for such families because they must also go about securing Afghan passports and identity documents. This is often despite having not regularly visited the country since emigrating over thirty years ago. ${ }^{36}$ Many younger men and women have never set foot in their 'home country', having been brought up in Saudi Arabia; they identify themselves in terms of their Central Asian and/or ethnic heritage as much as they do in relationship to their being 'Afghan'. A trader from such a background who had lived over four decades in Saudi Arabia and who now lives in Istanbul told me that 'such people are Afghan only in the sense that they hold Afghan passports. In other respects they are not Afghan at all - they are Bukharan or Turkestani.'

That many such families initially migrated to Saudi Arabia from Pakistan using Pakistani passports they procured while residing in the country as refugees further compounds the citizenship issues they face in the Arabian Peninsula. The names with which they travelled to Saudi Arabia and then to secure registration documents in the country are different from those in official records in Afghanistan, including allimportant 'national identity' (tazkira) and land registration documents. Since 2002, high-level representatives of the Afghan state have encouraged Saudi Arabia to allow Afghan citizens in the country to switch Saudi visa and residency permits registered in relation to Pakistani passports to their newly issued Afghan identity documents. However, Afghans in Saudi Arabia often told me that the country's officials have yet to grant Afghans the right to change the names in relation to which they are registered as residents in the country from those they acquired in Pakistan to those listed on their official Afghanistan documents. As a result, families encounter hurdles when seeking to claim rights to their property in Afghanistan because their Afghan passports list different names from land registration documents. And traders face difficulties during the course of international journeys - given that travel and mobility is an indispensable aspect of traders' activities, such difficulties also affect their ability to secure a livelihood. In particular, new technology used by border and security regimes creates especially significant difficulties for traders based in Saudi Arabia. Several Saudi-based Afghans, for example, have been denied entry to China since 2017, when the country began using facial recognition technology and fingerprinting to verify the

\footnotetext{
${ }^{36}$ Such issues can be rendered more problematic as a result of women from Central Asian émigré backgrounds having never been issued with identification documents in Afghanistan - a state of affairs that can effectively render them stateless (be watan).
} 
identities of visitors to the country. One evening in Yiwu, for example, a trader of Turkmen ethnicity from Afghanistan told me that one of his customers from Saudi Arabia had been denied permission to enter the country after border officials recognised that the man had made previous visits to China using a different name. Immigration officials reportedly told the man that as a result his visa was not valid; they subsequently deported him to Afghanistan and barred him from making further visits to China. I was told that these cases were so common in Afghanistan that the authorities in Kabul's international airport do not investigate citizens deported to the country on these grounds.

A major concern of some families is the prospect of being declared stateless (bewatan) by the Saudi authorities. This is a concern that relates especially to the grandchildren of families that migrated to Saudi Arabia over thirty years ago and have faced difficulties in securing access to Afghan passports, identity cards (tazkira) and other relevant documents identifying their ties to the country. One of my informants - currently based in Istanbul - told me how he had sought to travel with his infant son between two countries in the Gulf Cooperation Council, something that was usually possible while in possession of a residency permit from one of the relevant countries. The trader assumed that his son would be able to travel with him because he was in possession of a birth certificate identifying him as the recognised father. Border officials, however, informed the man that his son risked being declared stateless unless he was able to produce relevant nationality documents within the following month. The trader was only able to secure access to an Afghan passport for his son in the short period of time he was given because he was known to officials in Afghanistan's consulate in Jeddah who expedited his application for the relevant documents as 'a favour' (lutf). Instances such as this illustrate that if traders regularly move across national boundaries and develop a wide variety of strategies in order to do so, then this aspect of their lives is one experienced in relation to high levels of anxiety and can also have long-term consequences for their individual and familial lives.

The kafala system - whereby foreigners must register their visas and businesses in the name of a Saudi Arabian sponsor or kafeel - means that conducting business in Saudi Arabia is inherently risky for foreigners. ${ }^{37}$ A central reason for this is that while foreign traders invest capital in their businesses, these businesses are formally owned by their Saudi sponsors. In addition, while traders purchase and sell and lease valuable

${ }^{37}$ An extensive body of literature exists on the kafala system, especially in terms of its historical emergence and role in the exclusion of migrant worker communities from public life in the Gulf states. For a critical overview, see Vora and Koch 2015. On the historical emergence of kafala in Kuwait, see Longva 1997. 
commercial and residential properties (including shops but also warehouses and residential properties) among themselves, all such transactions are conducted through agents, proxy owners and intermediaries. Traders who have worked in Saudi Arabia often report to me the dangers of running a business in the country: sponsors may decide to take control of their company's assets and property. Afghan Central Asian émigré traders draw upon deep historic knowledge of such practices, which have been a norm among Central Asians based in the region since the nineteenth century. ${ }^{38}$ They also deploy cultural resources to offset the inherent risks that come from doing business under the name of a kafeel. Some of my informants have told me that their kafeel are third-generation descendants of 1920 émigrés from Central Asia. These people, they say, have 'become Arab'. They are, nevertheless, regarded as being more trustworthy partners than Saudi citizens lacking historic connections to Central Asia. Nevertheless, establishing a relationship with a Saudi citizen of a Central Asian émigré background is in no sense regarded as a failsafe route to a trustworthy relationship. A Farsi-speaking trader originally from the Samangan province in northern Afghanistan who is now based in Jeddah told me over breakfast in a hotel widely frequented by Central Asian émigrés in Istanbul that he owned a house in the city. In the summer of 2016, he had allowed his originally Kashgari kafeel to use the home for two weeks - four weeks later, the trader and his family were still staying in a hotel because the kafeel had decided to prolong his stay in Turkey. Shared regional and ethnolinguistic affiliation, then, is regarded as playing a positive role in attempts to foster relationships of trust but not in a simple or failsafe manner.

The traders say that Saudi officials are prone to grabbing capital on legal grounds from successful businesses that they know foreigners run. In this context, a key skill of being a trader in Saudi Arabia is recognising at what stage a business is likely to come to the attention of the authorities and to find appropriate ways of moving capital out of the country in the event that such attention results in the direct intervention of state officials into a business. The trade in goods between China and Saudi Arabia is one recognised vehicle through which to move capital; the standard practice of creating invoices for a higher value than the goods actually purchased is especially widely deployed with this aim in mind. Hajji Nazar, for example, was based in Yiwu in 2016 and ran a business that exported small commodities to Amsterdam - including trinkets for grinding hashish leaves. ${ }^{39}$ In the late 1970 s, he moved to Jeddah after coming

${ }^{38}$ Can 2020: 118-19.

${ }^{39}$ I visited De Bazaar in November 2018. In the Netherlands, the market has a reputation for being an exotic site of 'Oriental commerce'; Afghans, by contrast, widely refer to it as being a good place to engage in the sale of Chinese-made commodities of everyday use. 
under suspicion in Afghanistan for involvement in the Islamist party Hezb-e Islami. During that period, he worked as an accountant for a restaurateur of Afghan Central Asian heritage who also introduced him into the trade in commodities between Taiwan, South Korea, Hong Kong and Saudi Arabia. Having returned to Afghanistan after the communist government came to power, Hajii Nazar spent a period of time in jail before being released and spending several years fighting alongside Hezb-e Islami in 'the jihad' against the Soviet Union. After falling out with the party's leadership, he returned to Saudi Arabia at the onset of civil war in the 1990s and looked for the émigre trader for whom he had worked as an accountant over a decade before. The restaurateur's contacts told him that his former employee had moved his capital and family to Istanbul after his businesses had fallen 'under the gaze' (zer-e nazar) of Saudi officials.

Rising living expenses in Saudi Arabia - partly from a 'family tax' introduced by the Saudi Arabian government in 2016 - has also resulted in many Saudi-based Afghans closing their business in the kingdom. Foreigners based in the country must now pay a monthly sum per dependant: expats were required to pay $£ 21$ per dependant in 2016 a sum that rose to $£ 308$ in $2020 .{ }^{40}$ Such taxes have hit poorer families the hardest: families that earn a living working as labourers in warehouses and as sellers in shops are unable to afford the costs of annually renewing their residency permits, much less paying new taxes. Many such families also do not have the savings necessary to pay for expensive air tickets home, not least because families often might number a dozen or so individuals: they thus have little option other than to await their deportation by the Saudi Arabian authorities. The taxes have resulted in fewer difficulties for established business families. Yet even Afghan Central Asian émigrés who own their own businesses in the kingdom claim that a combination of rising costs alongside an economy weakened by conflicts in Syria and Yemen is significantly narrowing their profit margins. Difficulties arising from the taxes and Saudi Arabia's economy are also compounded by the country's 'Saudisation' policy that requires companies to employ a higher proportion of Saudi citizens than had been the case in previous years. ${ }^{41}$ As a result, major questions hang over the extent to which Bukhariyya Street will maintain its status as a central node of critical significance for the reproduction of Central Asian émigrés' commercial activities.

${ }^{40}$ Kerr 2016.

${ }^{41}$ On the impact of 'Saudisation' policies on migrant communities in Saudi Arabia, see, for example, de Regt, Tafesse 2015. 


\section{Out of Arabia}

Against the backdrop of these transformations in Saudi Arabia's political economy and its immigration policies, many Saudi-based Afghans have made or are in the process of making complex decisions about their futures in the country. The citizenship strategies arising from these calculations take into account multiple concerns. These include, of course, the possibilities for trade and the making of a livelihood in the countries to which they are considering relocating. A further - if not central - area of consideration revolves around the prospect of earning formal citizenship in a third country. This consideration is also connected to longer-term opportunities for their children's education and employment. However, it also relates to the important role played by neighbourhoods - such as that in Bukhariyya - in their collective worlds and identities, particularly in terms of the role played by social institutions in forging shared sensibilities and senses of familiarity.

The significance invested in the ability to establish and live within distinctive neighbourhoods distinguishes the role played by nodes in the networks of Central Asian émigrés in West Asia from the situation explored within the Eurasian corridor. Cultural and religious concerns play an important role in the decision-making processes of mobile Central Asian émigrés. As is the case with traders in the Eurasian corridor, traders identifying as 'Bukharan' operating across West Asia are culturally and linguistically versatile. They are at home across the Muslim societies of South and Central Asia, the Hejaz and the Arabian Peninsula more generally, as well as in Turkey. They speak Arabic, Farsi, Central Asian Turkic languages and modern Turkish. Those who travel to China for trade also often speak fluent Mandarin and/or Cantonese. Most are also fluent in Urdu, having lived in Pakistan and interacted with South Asian migrants in Saudi Arabia and the other countries in the Arabian Peninsula in which they have lived and worked. Yet they also identify important limits to the type of worlds in which they established nodes for their community. In contrast to the Afghan networks in post-Soviet Eurasia, the émigré traders in West Asia often remark that 'their people' chose to live in Saudi Arabia because 'there are few greater blessings than living close to the sacred cities of Mecca and Medina'. They also regularly say that they seek to ensure that their families live in countries in which 'the call to prayer can be heard'. This does not mean that there are no Central Asian émigré families working beyond the Islamicate spaces of West Asia: some émigré families are commercially active in the West - for instance, in London, the United States and Canada, as well as Europe. Single men and less often families also live in China and other East Asian countries 
that play a role in their business activities. Such scattered families often aspire, however, for their families to collectively live either in neighbourhoods in Saudi cities with a high density of Central Asian émigrés or in the Zeytinburnu area of Istanbul. Traders of Central Asian émigré backgrounds in London, for example, arrange for their families and their elderly parents to live in Istanbul, where, they say, they can live in an Islamic cultural environment, engage with their community and hear the sound of the call to prayer.

\section{Becoming Kazakh}

Families who have taken the complex decision to leave Saudi Arabia after living there for several decades mostly regard returning to Afghanistan as the least attractive option available to them. A substantial segment of Jeddah's Afghan Central Asian population hails from parts of northern Afghanistan that since 2009 have seen levels of violence perpetrated by the Taliban and ISIS-affiliates rise significantly. Families with little capital at their disposal have relocated themselves and their families in Afghanistan: most have moved to cities in the north of the country (especially Mazar-e Sharif), though some have returned to the villages in which they were brought up and to which they have access - albeit in highly contested ways - to ancestral plots of land. (I explore this context in detail in Chapter 6.)

For most traders and their families, however, the prospect of returning to Afghanistan with children born and raised in Saudi Arabia is painful. As a result, many traders identify multiple options in terms of where to move with their families. A small proportion of such families have relocated to Kazakhstan. Citizenship policy in Kazakhstan has provisions for the return of Kazakh diasporas under the oralman policy. ${ }^{42}$ In recent times, the Kazakh state has sought to deploy this policy to increase the proportion of ethnically 'Kazakh' peoples living in regions with a predominantly Russian population, most especially in the north and west of the country. Moving to Kazakhstan under such provisions is a legal possibility open to some émigré families if they are able to demonstrate their descent from a particular Central Asian 'tribe' - the qarluq. The law in Kazakhstan identifies this tribe as being ethnically Kazakh, even though it is widely distributed across Central Asia due to historic migratory patterns and long-term political processes. In Afghanistan,

42 The oralman is the Kazakh term to refer to Kazakhs living in the diaspora who have returned to the country since 1991 . On policy relating to returnees and debates about it in Kazakhstan, see Kuşçu 2013 and Genina 2016. 
qarluqs are dispersed across the northern regions of the country and widely referred to as being ethnically Uzbek. ${ }^{43}$ Indeed, most families identifying as qarluq in Afghanistan speak Farsi: as a result, they are unable to apply for Kazakh citizenship on linguistic grounds but are eligible to do so based on their genealogies (nasabnama). In Afghanistan, ethnic Kazakh leaders (kalanha) and elders (mui safed) verify the genealogies of families seeking residency in Kazakhstan. It is the prospect of formal citizenship that motivates most émigré families to relocate to Kazakhstan. But the country is also regarded as a viable place in which to trade, being the site of both established post-Soviet bazaars (similar to those explored in Chapter 2) and different types of commercial opportunities arising out of the Eurasian Customs Union and investment in infrastructural links with China. ${ }^{44}$ Many of the traders with whom I spoke in Jeddah also had reservations about moving to Kazakhstan: it is widely thought among Central Asian émigrés that women in the community would be unable to wear the face veil (chadari or niqab in Arabic) in the country as a result of its Soviet heritage, and that, consequently, relocation to the country would place obstacles in front of their mode of living.

\section{The United Arab Emirates}

A destination for many wealthy traders is the UAE, especially the cities of Dubai and Sharjah. Saudi-based émigrés have enjoyed connections to other émigré families settled in Dubai for several decades, often being involved in the export of commodities (prayer mats and ready-made clothing in particular but also more novel and niche items such as electronic prayer beads) from Dubai's Murshid market to Jeddah and Istanbul. Indeed, there are around thirty shops owned by Central Asian émigrés in the market, several of whom also run businesses in Jeddah a handful of such merchants also own carpet factories in Istanbul. In addition to investing in such businesses in the UAE, formerly Saudibased Afghans are also active in the UAE's busy restaurant sector, mostly running establishments that purvey variations of Afghan cuisine to an international, rather than Afghan, clientele. Since the introduction of VAT in Dubai in 2018, the historic city centre's (Deira) status as an infrastructural trading node has undergone significant changes and is less widely used as a procurement node for Asian and African commodity traders. As a result, Deira is no longer an especially attractive destination in which to invest and is increasingly a locale that émigré families are

\footnotetext{
43 On the complexity of Uzbek-Kazakh identities, see Bregel 2009. ${ }^{44}$ Karar 2013.
} 
actively seeking to leave. Furthermore, while restrictions on foreigners doing business in the UAE are considerably less strict than those in place in Saudi Arabia, long-term residents in the UAE have no rights to citizenship or long-term residency; they must also negotiate access to capital used to purchase homes, businesses and warehouses with the local inviting partner ( $a r b a b)$. Both Afghan and Central Asian émigré families based for decades or more in the UAE have thus increasingly sought to relocate to countries that do hold out the promise of citizenship to immigrants and their families. One of the most favoured destination points is Istanbul.

\section{Turkey}

The most successful of Afghanistan's Central Asian émigré merchants in Saudi Arabia and the wider West Asian corridor have preferred to move their families and capital to Turkey. In terms of trade and commerce, the wealthiest traders are able to open factories in Turkey in which they produce commodities, especially machine-made carpets. In doing so, such traders are building on the historic role played by Central Asian merchants in Turkey in this activity over the past half a century or more. Carpets produced in Turkey are then mostly exported to the Gulf countries. In order to partake in such activities, traders divide their time between their factories and families in Turkey and their wholesale businesses in the UAE and Saudi Arabia; fathers entrust their children to run either a shop or a factory during their absences from one or other of the settings in which they work. For traders who do not have access to sufficient capital to invest in a factory in Turkey, relocating family members to the country is regarded as a prudent step to take: doing so reduces household costs as there is no need to pay the expensive fees required to renew residency permits. Traders generally regard the cost of living in Turkey as being more affordable in comparison with the UAE, and, increasingly, Saudi Arabia.

Traders with sufficient capital often secure access to Turkish residency permits (eqama) and sometimes also citizenship. It is common for traders in the process of seeking citizenship in Turkey to emphasise their historic status as belonging to Central Asia's 'Turkic' communities: doing so is recognised by them and the authorities with whom they interact as legitimising their collective and individual citizenship claims in Turkey. Traders regularly also report that holding Turkish citizenship is of value not only in terms of securing residency rights in the country but that it also improves their ability to work abroad, especially in Saudi Arabia - 'if you hold Afghan documents', remarked one trader in his mid-thirties who lives in Yiwu and runs businesses in Saudi Arabia, Turkey and 
Afghanistan, 'the Saudis treat you as if you are nothing. But if you claim you are Turkish and you have access to Turkish consular representation, then they at least think twice about what they do to you.' Historians have recently explored the ways in which Afghan itinerants (mostly pilgrims and merchants) claimed multiple forms of imperial jurisdictional subjecthood in the years in which a treaty with the British government denied Afghanistan's right to an independent foreign policy. ${ }^{45}$ Afghans travelling in West Asia and Eurasia selectively claimed access to protection from Ottoman, Russian imperial and British Indian authorities. ${ }^{46}$ Central Asian émigrés regard Turkish citizenship in a similar manner, meaning that acquiring it offers an important avenue for navigating the fraught geopolitical worlds across which they move.

Traders deploy various strategies to secure access to Turkish citizenship and residency rights. Several of the Afghan traders with whom I have spent time successfully acquired Turkish citizenship in the 1990s and 2000s - one of the most straightforward ways in which they did so was to rent or occasionally purchase property in Turkey. Since 2018, legislation in Turkey on the granting of residency permits has been tightened: immigrants are now required to have bought a property in the country to the value of $\$ 200,000$. Such legislation has made the move to Turkey for traders from Saudi Arabia harder though not impossible. There is a healthy trade between the country's officials and merchants with sufficient capital to pay substantial bribes in the procurement of Turkish residency permits and even citizenship documents, for example. 'Estate agents' (rahnama-e mamalat) run by Afghans are also able to produce receipts that show purchased property as being more valuable than the actual cash transaction.

The institutional life of Central Asia's émigrés in Turkey also plays a major role in facilitating the ability of individuals and families to secure access to citizenship and residency rights in Turkey. Associations (anjomanha) established by Afghans in Istanbul are frequently founded in relationship to an explicitly ethnolinguistic Turkic identity, most conventionally that of 'Afghan Turk'. Turkey has for long cultivated close relations with Afghanistan's Turkic-speaking communities. Central Asian communities established themselves in Turkey in the wake of the Bolshevik Revolution; in the 1980s, several thousand Afghans were granted residency and citizenship rights in Turkey on the basis of their being Uzbek- and Kirgiz-speaking 'Turks' ${ }^{47}$ As we have already seen,

${ }^{45}$ On the legacies of this history for independent Afghanistan, see Drephal 2019.

${ }^{46}$ Afghan itinerants (mostly pilgrims and merchants) claimed multiple forms of imperial jurisdictional subjecthood, including of the Ottomans, the Russian Empire and British India. See Ahmed 2016, Can 2012, Can 2016 and Stephens 2014.

${ }^{47}$ Kreutzmann 2015. 
a central aspect of Turkey's foreign policy - the so-called 'pivot to the East' - has been its emphasis on rebuilding relationships with contexts that were formerly part of or in a close relationship with the Ottoman Empire. Afghanistan's Central Asian émigrés have increasingly identified themselves in relation to this geopolitical project: the granting of Turkish citizenship is widely regarded by the community as arising directly from their 'Turkic ancestry' and support for the project to reinvigorate Turkey's Ottoman imperial legacy. The choice by Afghans in Istanbul to designate their associations in Istanbul as 'Afghan Turk' reflects this alignment between their identity project and Turkey's geopolitical project. Afghans in the country widely regard such associations as playing an important role in shaping their ability to reside legally or semi-legally in Turkey. Several Central Asian émigrés based in Istanbul told me that community organisations (dernigi) play an important role in mediating the citizenship and residency applications of Afghans in the city, especially those claiming Turkic forms of ethnic identity. Indeed, it is also purported to be the case that immigrants from Central Asian countries especially Uzbekistan - seek affiliation with such organisations knowing that their citizenship applications stand a better chance of success if they can claim Afghan national identity; doing so allows them to claim refugee status and benefit from relationships between figures of influence in the country's Afghan communities and relevant government officials. ${ }^{48}$

Afghans in Turkey are themselves critically aware that the ways in which they identify their backgrounds, identities and collective histories are interleaved with geopolitical projects. Central Asian émigrés in Zeytinburnu openly reflect, for instance, on the extent to which they have come to emphasise the Turkic aspects of their identity after moving to Turkey. In many regions of Afghanistan, the designation of being 'Turkic' (turktabar) has been invested with increasing political significance since 2002. This is partly a result of the country's constitutional system, which was developed in the context of the US invasion of the country in 2001 and the Bonn Agreement signed in December of the same year. The constitution seeks to distribute the ethnic balance of power in the government at various levels, although especially by means of a presidential system that is accompanied - theoretically, at least - by the appointment of two vice-presidents. ${ }^{49}$ In the context of Afghanistan's post-Bonn elections, electoral teams largely seek to select candidates for

${ }^{48}$ The role played by such association heads as mediating figures between migrants and state authorities builds on a long tradition of the shaykhs of Sufi lodges acting as the guarantors of claims made by foreign Muslims to become Ottoman subjects. See Can 2020: 119.

${ }^{49}$ Rubin 2014. 
such appointments from varying ethnic constituencies. ${ }^{50}$ As Niamattulah Ibrahimi has argued, the inclusive design of the post-Taliban government ... has inadvertently contributed to a more popular ethnicisation of politics'. ${ }^{51}$ One of the results of such arrangements is that 'Turkic' Afghans play a significant role in national politics: they are regarded as being able to deliver a substantial amount of votes for powerful Pashtun and Tajik politicians and do so in return for Turkic representation at the highest level of government. The politics of ethnicity in Afghanistan masks, however, a much more fluid range of identities that have been important in the past and remain so today, including those related to the category of 'Turkic'. ${ }^{52}$ A representative of one cultural association based in Istanbul who is from Afghanistan's northern Takhar province and had lived for several years in New Delhi before moving to Turkey made the following remark to me in August 2017: 'Back in Afghanistan, we knew we were Uzbek but we only ever spoke Farsi. I learned more Uzbek in Istanbul than in my homeland.'

The community in Zeytinburnu nurtures and maintains a type of social institution that has a long history in West Asia as being central for sustaining the identities and activities of mobile societies: Sufi lodges, referred to by the traders and the communities they form as tekke in Turkish or taqiya khana in Farsi. ${ }^{53}$ The foundation of tekkes by mobile societies in nodes of commerce, trade and travel across West Asia is a recognised aspect of the region's history. In the nineteenth century, however, the establishment of tekke in Mecca and Medina by Muslims from societies outside the Ottoman world became a source of considerable tension. The Ottoman authorities came to regard such institutions as vehicles used by European powers to extend their influence beyond territorial boundaries. As a result, the Ottoman authorities introduced legislation in 1867 that banned 'foreigners' from purchasing land in the Hijaz. Can has shown, however, that the Ottoman state also depended on foreign philanthropic funds to finance the construction of lodges for the growing numbers of pilgrims and migrants visiting Mecca and Medina as a result, officials turned a blind eye to Central Asian merchants purchasing land and establishing endowments (waqf) using local intermediaries. ${ }^{54}$ Endowments established in this manner mostly provided lodgings for merchants and pilgrims from Central Asia and were distributed not only in Mecca and Medina but also in cities along the haji routes, including Damascus, Jeddah and Istanbul. Muslims could

\footnotetext{
50 Sharan and Heathershaw 2011 and Sharan and Bose 2016. $\quad{ }^{51}$ Ibrahimi 2017: 219.

52 Rasuly-Paleczek 1998. ${ }^{53}$ Can 2012, Green 2010 and Martin Smith 1980.

54 Can 2020: 111-19.
} 
designate tekke as available for general use or by Muslims from particular regions. The history and development of religious institutions of importance to mobile societies in West Asia has, then, for long been interleaved with competing projects of geopolitical influence and containment. ${ }^{55}$

The history of such institutions is also embodied by mobile merchant families active across the region. The great-grandson of a wealthy Central Asian émigré from Andijon - a Central Asian khanate that occupied an important role on multiple trading routes - reported to me during a series of conversations in Istanbul (where he now lives and conducts business) during August 2017 that his grandfather had established a waqf in Mecca in the 1920s. The building was designated by his grandfather as being available for use by all Muslims (a waqf al muslimin), rather than his kin or indeed people from their region of Central Asia. It comprised rooms intended for use for a diverse range of activities. Rooms were designated for use as lodgings for pilgrims making the haji (musafir khana; hajji khana), and others were intended for occupancy by widowers. Still more rooms were open for those wishing to organise social and religious events important to Muslim communal life, such as sacrificial feasts of remembrance (khairat). He told me that the waqf continued to function in Mecca, but that his family no longer oversaw it and had become embroiled in a legal dispute over its management with another group of kinsmen.

Central Asian merchants continue to play a role in the management of tekkeltaqiya khana in Jeddah, Mecca and Medina. As Can has explored, tekkes were closed by the Turkish Republic as a result of secular legislation being introduced that targeted Sufi institutions in the country; despite such policies, they continued for decades to play a role in the fortune of migrants. ${ }^{56}$ In the context of the planned relocation of Turkic Afghan refugees in Turkey in the 1980s, new types of social and religious institutions were established that played some of the roles that tekkes had occupied in the past. In Zeytinburnu, two waqf (vakif in modern Turkish) have been established by groups of successful traders who pooled together collective resources. These vakif are often referred to by members of the community as tekke and taqia khana and are available to them to hold important collective events. While Bukharan émigré traders state that these institutions are no longer used for Sufi practices such as the collective recitation of the names of Allah (zikr), they are spaces that are regularly deployed by the traders for the holding of sacrificial feasts (qorbani), charitable feasts (khairat)

55 On the significance of circulation and mobility to waqf in Asia, see Fauzia Mostowlansky and Yahaya 2018.

${ }^{56}$ Can 2020:182. 
and other funerary rites, especially fatiha, or prayers of remembrance. The complex and multifaceted nature of the connections between tekkes and the collective identity of Central Asian émigrés suggests that, even in the face of a reform-minded Islam that is hostile to Sufism in Saudi Arabia and of the secularising logics of the Turkish state, it is impossible to discount the ongoing importance of Sufi ideas, institutions and practices to this transregional community.

Émigré families moving to Istanbul from Saudi Arabia initially bought homes in a neighbourhood long favoured by the city's Central Asian communities: Zeytinburnu. Many émigré families moved into rented flats in the neighbourhood, with some buying properties that they later developed - often increasing the size of the apartments and turning ground-floor flats into basements used as small-scale stitching workshops, largely employing Afghans and Syrians as their workforce. The Zeytinburnu neighbourhood in Istanbul is now an important node for the commercial and affective lives of Afghanistan's Central Asian émigrés. It is usual for such families to maintain business activities in Jeddah while basing their families in Zeytinburnu, which means that their children have easier and more affordable access to higher education than is the case in Saudi Arabia. More and more traders are also opening businesses in Istanbul, especially in the field of property (where they procure accommodation for families moving from Afghanistan to Istanbul) and in the money exchange and travel agency businesses (both of which have expanded in significance as Afghans based in the city have increased in number).

Community life is a critical feature of Central Asian émigré experiences in Zeytinburnu, and, as we have seen, a motivation for people from such backgrounds to relocate to the city. Many families visit Istanbul in the summer to escape the heat of Jeddah, as well as to order Turkish-made carpets and clothes to be delivered to Saudi Arabia on time for sale during the great haji pilgrimage. These traders and their families also attend or organise wedding celebrations in the city. Marriages are contracted between trading families long known to one another in Saudi Arabia and who now lead split lives between Jeddah and Istanbul. Central Asian émigré newcomers to Istanbul also forge marriages with the children of families who were resettled in Turkey in the 1980s and have established successful businesses - especially in the fields of clothing and machine-made carpets - over subsequent decades. In this respect, Zeytinburnu combines in important ways a status as a node for trade and infrastructure as well as for the sociological and commercial reproduction of Central Asian émigré trading networks. This node furthermore is concentrated in a specific part of Istanbul - Zeytinburnu - giving further 
force to Anderson's conception of the social institutions that traders establish as akin to those of the neighbourhood. In this case, however, the neighbourhoods established by traders are also 'partial'. Ho argues that understanding transregional dynamics requires the development of models of society that can embrace the type of 'small, mobile, and less integrated' social formations that have largely not been encompassed by social science studies of large-scale social aggregates. According to Ho, accounts of multiple 'partial communities' - defined as communities that are connected to each other in the context of an Asia-wide arena of circulation and interaction - afford the possibility of 'spatially expansive' yet 'integrative' accounts of mobile societies. ${ }^{57}$ It is helpful to think of Jeddah and Zeytinburnu as two geographically distinct neighbourhoods that are nevertheless of collective importance to Central Asian émigré networks. Jeddah was historically the primary seat for the capital accumulation of Central Asian émigrés active in the carpet business and commodity trade; Zeytinburnu has increasingly become the centrally important node for this network's sociological and cultural reproduction, though in the context of the changing nature of Saudi Arabia's political economy it is also playing a progressively more important role in the network's commercial profile, especially as a site in which capital is invested in property and industry.

There is nevertheless considerable uncertainty in the mobile society about the future significance of Zeytinburnu as a shared site of cultural and social reproduction for Central Asian émigré trading networks. At one level, this neighbourhood of historic significance for Central Asian émigrés is no longer regarded by families as the most suitable site for them to settle in Turkey. From the 2010s onwards, it has become increasingly popular among Central Asian émigré families to invest in the new housing and commercial developments that have sprung up in western Istanbul under the regime of President Tayyip Erdoğan. Beylikdüzü, for example, is a new housing and commercial development in western Istanbul that is regarded as being a safer and more convenient locale for family life than the bustling and densely populated neighbourhood of Zeytinburnu. Several Central Asian émigré families have remarked to me that they avoid visiting Zeytinburnu. A trader in his mid-forties who deals in carpets and has offices in Turkey, China and Dubai, for example, told me that Zeytinburnu is full of recently arrived (naw umada) Afghans who have 'no understanding of how to behave' in Turkey and fight with one another, and that gangs comprising different ethnic groups are also present in the neighbourhood. For traders such as this one, living outside

${ }^{57}$ Ho 2017. See also Ho 2014. 
Zeytinburnu establishes a boundary between themselves and Afghan 'migrants' and 'refugees'; residing in the modern apartment blocks of Beylikdüzü also makes it easier for their women and daughters to visit public spaces without the risk of being seen by Central Asian émigré families known to them. One émigré trader I have known for ten years who runs an import-export business between Turkmenistan and Dubai invited my family and me to visit his home and to meet with his mother, wife and daughters, all of whom had recently relocated from Dubai to Istanbul. He told his daughter aged in her early twenties to drive us around Beylikdüzü, telling us that we could never do such things in Afghanistan, Dubai or, for that matter, Zeytinburnu. The active choice of traders such as this one to reside with their families in locales in which few of their fellow Central Asians live suggests imperatives for family living that do not revolve around the significance of collective residency in specific neighbourhoods.

At another level, the extent to which Istanbul is likely to have the same degree of commercial significance for émigré networks as Jeddah in previous decades is also a source of reflection. Istanbul's status as a node in the cultural and social reproduction of Central Asian émigré life is undisputed, yet its capacity to act as node of trade and infrastructure is a source of serious concern for many émigré families. These families and their commodity trading businesses have profited over decades from low tax import tariffs in the Gulf countries. By contrast, Turkey continues to be a major producer of the types of commodities in which the émigrés deal (notably machine-made carpets and ready-made clothing); such commodities are subject to hefty import duties in Turkey. As a result, a trader moving a business from Jeddah to Istanbul is usually unable to simply shift his operations from one city to the other but is instead required to consider developing a different type of commercial model in Turkey, most usually of a small-scale industrial nature.

The traders also say that their businesses were successful in Saudi Arabia because relatively few Saudi citizens were involved in the trade in small commodities, and niches emerged in the country's economy that could be filled by different groups of 'foreigners' specialising in specific commodity types. By contrast, in Turkey traders often remark that 'everybody is a trader', and therefore there are few opportunities to capture and shape a specific niche. The most obvious niche open to traders moving their operations to Istanbul revolves around the running of businesses that cater to the needs of migrants entering the city. Most especially, Afghan traders have opened grocery shops, travel agents, restaurants, businesses importing the specific varieties of rice, tea and spices favoured by Afghans and Arabs, estate agents and Internet cafés 
that also act as money transfer businesses (hawala). The trader of Andijoni heritage who has spent most of his life in Saudi Arabia, mentioned earlier in connection to his family's waqf in Medina, for example, ran a business importing rice and spices to Turkey from India - the line of trade in which his family had been active for decades. In Istanbul, the rice he imported was mostly of the type preferred by the expanding communities of Arabs, Afghans and Iranians living in the city. The fortunes of his business and others like it, however, depend to a significant degree on the policy of Turkey towards immigration from the wider region, including undocumented migrants who regularly stay in the country on long sojourns or en route to Europe. ${ }^{58}$ A 2016 agreement between Turkey and the EU, for example, resulted in more undocumented migrants from Afghanistan being deported by Turkey rather than being tacitly allowed to travel on to Europe using informal routes, as had previously been the case. Indeed, the trader told me that he was unable to make sufficient profits to maintain the vitality of his business in Turkey. Against this backdrop, successful traders maintain businesses in Saudi Arabia and the UAE while also exploring opportunities in Turkey. As a result, if Istanbul is of growing significance to the cultural and social reproduction of the community, then cities in the Arabian Peninsula, most especially Jeddah, continue to hold commercial relevance for the networks. In this way, Zeytinburnu and Jeddah function as two dimensions of a partial neighbourhood that is significant for the dynamics of the mobile society as a whole.

\section{Political Contestations of Culture and Heritage}

Central Asian émigré traders collectively agree, then, that Turkish citizenship invests them with a national identity that carries positive legal and cultural implications. Indeed, in their discussions with one another, traders of these backgrounds regard being identified as Turkish rather than Afghan as better reflecting their cultural and historical backgrounds. An understanding of the traders' citizenship strategies therefore requires a consideration of their economic goals and motivations, as well as the ways in which they can emphasise particular aspects of their ethnolinguistic, regional and religious identities in a manner that calibrates with the ideological currents informing the geopolitical projects of West Asia's states. Citizenship manoeuvres such as these, as well as the attendant shifts in relation to geopolitical projects they signal, are the focus of

58 There is a voluminous literature on the EU's policy regarding refugees and the role of Turkey. See, notably, Schuster 2011. 
intense and critical discussion by the traders. Far from merely forming strategies in relation to a consideration that the outcomes might have for their individual and collective futures, the traders debate the political implications of the decisions they make about where to live and how to earn a livelihood. The embrace of Turkey, for example, is a source of much critical discussion among these families. Traders ask one another the extent to which thinking of their relationship to Turkey in terms of 'authenticity' and in opposition to being 'Afghan' holds negative as well as positive implications. As I have noted already in the chapter, relatively few of the émigré families that now trade in the West Asian corridor make frequent visits to Afghanistan. They do, however, arrange marriages between their children and suitable families in Afghanistan, something that brings them into conversation and contact with émigrés living in their former temporary homeland. Central Asian émigrés based in Turkey increasingly depict themselves as a Turkic 'diaspora' from a lost Central Asian homeland. By contrast, émigrés in Afghanistan often remain deeply invested politically, economically and culturally in the ongoing presence of the community in the country. Such differences in perspective reflect the shifting identifications of many 'diaspora' communities and the analytical distinction advanced in this book between 'diasporas' and 'mobile societies'. Whereas mobile societies bring to light the sustained and ongoing participation of communities in and across multiple contexts, the notion of diaspora is associated in much scholarly writing with the binary distinction between 'home' and the 'host' 'societies'. 59

Abdul, for example, was a trader of mixed Uzbek and Turkmen heritage who lived in a house in the outskirts of the northern city of Mazar-e Sharif until his death in 2018. In the autumn of 2016, I participated in a lively debate between Abdul, who often travelled to the Central Asian states to trade but maintained his family base in Mazar-e Sharif, and a Turkmen Afghan émigré who had moved his family to Istanbul in 2011. Abdul told his guest from Turkey that he was opposed to émigré Turkmen families leaving Afghanistan to live in Istanbul. He said that they were uncritically accepting an exclusive and simplistic form of Turkish national identity. The Turkish state, he went on to argue, was interested in their capital and status as voters rather than the unique nature of their Turkic culture and society and its importance to the history of modern Turkey. He argued that Afghanistan's Turkmens should be committed to protecting their people's place in a specific regional

59 See, for example, the contrasting approaches of Brubaker (2005) and Safran (1991). For an approach focusing on the need to understand the importance of 'third' settings as much as 'home' and 'host' societies, see Ho 2017. 
geography that has been of significance to the community for centuries: if influential members of the community continued to migrate (kuch kardan) to Turkey, he argued, this would act as a fillip to exclusivist forms of Afghan national identity, a political development that would diminish the vitality of their geography. By contrast, the Istanbul-based trader argued that for decades the Afghan state had not supported émigrés based in northern regions of the country - in Turkey, by contrast, they could lead a respectable and stable life but also keep their culture and identity intact.

Debates such as these in which traders advance different positions about the benefits or otherwise of aligning their identities with those of modern Turkey also carry on apace in the trading nodes of the West Asian corridor of connectivity. During my research in Saudi Arabia, I was invited by a trader of Turkmen ethnicity from northern Afghanistan to visit him at his home in Riyadh. The trader ran a successful furniture business in the country's capital and also owned shops in Jeddah's Bukhariyya neighbourhood. My host had invited other Afghan Turkmen traders living in Riyadh for an evening of discussion (gap; gashtak) - we ate traditional Afghan dishes, listened to two men sing Turkmen songs to the sound of traditional musical instruments and then discussed the significance of modern Turkey to their identities. ${ }^{60}$ Having seen a news clip about Turkey, two of the other guests present argued that Turkmens naturally belonged to Turkey - the two men had even gone on Turkish-run tours to China's Xinjiang region to explore the region's distinctly 'Turkic' heritage. My host, by contrast, said his community should be suspicious of Turkish policy towards speakers of Turkic languages in Central Asia: if Turkish political leaders might speak of Central Asian Turks as their 'brothers', he cautioned, then such groups were treated in the country as a source of cheap labour as well as hard capital.

Such discussions point towards the processes through which the traders' identities undergo shifts in relation to the geopolitical projects of state actors active across the Eurasian arena, yet such shifts also have important ramifications for Afghanistan itself. They also demonstrate that the traders think critically about the ideological projects advanced by the states in which they live - some if by no means all of the traders recognise the exclusionary realities that lie beneath the rhetoric of panTurkic unity advanced by Turkey in its 'look East' policy. ${ }^{61}$

${ }^{60}$ For an insightful discussion of the significance of such gatherings for social life in Central Asia, see Harris and Kamalov 2020.

${ }^{61}$ An extensive body of historical literature has drawn attention to the mismatch between the rhetoric of pan-Turkic and pan-Islamic unity and the strategic manner in which the Ottoman Empire actually related to regions of the world that were home to Turkic populations. See Can 2020: 124. Cf. Meyer 2014. 


\section{Conclusion: Trading Networks; a Comparative Historical Approach}

Chapters 2 and 3 focused on two core axes of Afghan mobility along Asia's contemporary Silk Roads - one that connects China to the former Soviet republics and increasingly Western Europe, and the other to West Asia, notably Turkey and the Arabian Peninsula. These two axes of connection are, however, disconnected; they are also characterised by the contrasting cultural and political priorities and outlooks of those who form them.

Afghan traders in the former Soviet Union tend to share an emphasis on their culturally Afghan identities. They also promote an understanding of themselves in the societies in which they live as being if not onedimensionally secular, then avowedly flexible in terms of their cultural and religious identities. This mode of cultural and religious identification is especially visible in the emphasis they place on their ability to partake in public forms of social life; traders in this corridor also regard such behaviour as a vehicle to demonstrate their flexibility, success and commercial acumen to one another. They are also visible in the types of institutions they establish in the settings in which they live, notably those framed in terms of 'the Afghan diaspora'. The events organised by such institutions also place much emphasis on the cultural needs of overseas Afghans, as well as the political dynamics of Afghanistan. The forging of ties with local communities through marriage and friendship - communities that rarely identify as 'Muslim' - demonstrates such cultural flexibility. An area where the performance of flexibility is especially visible is that of marriage - many Afghan traders in the former Soviet Union have married local Russian and Ukrainian women; doing so enables them to demonstrate the flexible nature of their identities and modes of acting but also to expand and consolidate their trading activities in multiple nodes.

By contrast, the émigré Bukharans active in West Asia do identify as 'Afghan' in particular circumstances, and rarely if at all contest or refuse this aspect of their identities, yet they also collectively orient around a conception of themselves as émigré Central Asians - in some contexts, self-representations congeal in relation to the eighteenth- and nineteenthcentury political entities in which their families lived, notably the Emirate of Bukhara. More recently - in the context of Turkey's pivot to the East the émigrés have also actively identified and engaged with the category of Turkic. Afghanistan plays a complex role in the identifications of most traders in this group. Rarely regarded as 'home' in any simple sense, it is, however, a country that is invested with emotional significance in both more positive and negative ways. Afghanistan is also of practical 
significance for the traders: many of them are Afghan citizens, and others are able to use their past residence in the country to claim citizenship in the contexts to which they move. These merchants also collectively emphasise the importance of Islamic thinking, practice and institutions to their public identities and activities. Institutions such as taqiya khana/ tekke are maintained over decades and are registered with religious bodies such as the Turkish vakif department; they are used specifically for performing Islamic rituals important to the collective life of the community. The extent to which Islamic values and models for action shape Bukharan émigré networks is also visible in the types of choices they make about where to live. Most traders emphasise the importance to them of their families living in culturally Islamic contexts, be these in Saudi Arabia or Turkey. In this sense, ideological projects of pan-Turkic and panIslamic unity inform the thinking and identities of these traders in a manner that reflects the context they inhabit. At the same time, the traders are often critical of such ideologies and hold divergent views of them.

There are clear differences in the cultural and political priorities of the networks sketched out in this chapter; these variations also assume a material form in the type of social institutions that the chapter has argued played a critical role in the commercial and cultural reproduction of the networks under study. Differences in outlook between the networks also reflect the varying ways in which they are structured and the forms of behaviour facilitated, shaped and encouraged by such structures. In this sense, Afghan traders in Eurasia organise their activities in relationship to multiple nodes that hold various forms of commercial, cultural, sociological and economic significance. Such nodes are geographically scattered; they are constantly renewed and recreated in the face of changing political and economic circumstances. The relative influence of particular nodes on the activities of the network more generally vary: some are of critical commercial importance, while others are significant for the networks' cultural and sociological reproduction; still more seek to combine multiple functions. In the case of the Central Asian émigrés in West Asia, traders seek to establish all-influential nodes that combine commercial, social and cultural functions. Traders in this network emphasise the importance of their families living together in close proximity and in specific neighbourhoods. There are currently two such physical neighbourhoods (Bukhariyya in Jeddah and Zeytinburnu in Istanbul). The degree of connectivity between these neighbourhoods suggests they are best analysed as a 'partial neighbourhood': a shared site of sociality that is dispersed spatially, with each locale requiring the co-presence of the other. This complex arrangement has arisen in the context of the traders' 
cultural preferences for living communally and as a strategic response to Turkish and Saudi policies, especially in relationship to immigration, citizenship and policy towards business in general and international trade in particular. So, while geographically dispersed, Central Asian émigré networks more closely approximate the model of the mononodal network introduced earlier. They emphasise the importance of their being a central node that acts as a departure point for women, credit, commodities and religious authorities.

Despite important divergences in the nature of these two trading networks, there are also important areas of convergence. Historical processes played out over the longue durée are important to the dynamics of both of these contemporary networks. Afghan traders in Eurasia and Central Asian émigré merchants in Bukhara both work in contexts in which the communities with which they identify have for long occupied important commercial niches. Afghan merchants have dealt in Central Asia's renowned fruits in Russian markets for at least two centuries; Bukharan merchants have historically acted as mediators between the Central and West Asian commercial spheres. As importantly, both networks also share a comparable elasticity in the ways in which they incorporate successive waves of traders into their activities and worlds. Neither Eurasia's Afghans nor West Asia's Central Asian émigrés form bounded communities strictly determined by ethnolinguistic or ideological boundaries. Complex and multiple layered identities and ideological influences inform the dynamics and cultural content of these networks. Erstwhile Afghan communists share their commercial spaces with newer waves of entrepreneurial migrants who identify with Islamist movements or have served as translators for the US army in Afghanistan. Central Asian émigrés' networks collectively orientate around shared Islamic values and modes of community life. Yet in important respects, they are also layered in complex ways: this is most clearly illustrated in their relationships with historic communities of Central Asians in Saudi Arabia and with newer and older communities of 'Afghan Turk' refugees in Turkey.

The networks are also similar in their ability to work at the intersections of multiple geopolitical projects. In the case of the Afghan traders in the former Soviet Union, the traders simultaneously thrived in the context of the Soviet collapse and China's ascension to the WTO in 2001. They successfully forged an important medial position between these two contexts. More recently, these traders have maintained a foothold in Russia in the context of the country's reinvention of its place in Eurasia, most especially seen in the example of the Eurasian Customs Union. Yet they have also navigated the tensions this has spawned, most noticeably with Ukraine, but also with China and the direct role that the People's 
Republic plays in Eurasia's political economy, initially by way of its 'Look West' policy and currently in the form of the Belt and Road Initiative. The traders have also been successful in extending their networks within the European Union. Similarly, Central Asian émigré networks have also engaged with multiple geopolitical projects, including the growing emphasis placed by Saudi Arabia on its relationship with China and, most recently, Turkey's pivot to the East and the attempt to garner identities based on the history and geography of the Ottoman Empire.

But if both networks have adapted to such geopolitical projects, then it is important to emphasise that they have not come to be defined by them. The geographical connections, routes and imaginations of traders in both of the networks are not opposed to state boundaries and geopolitical projects - nor are they simply derivative of them. Rather, their own routes and geographical imaginations are imbricated and layered in a complex and often contingent way within and across states and prominent geopolitical projects. Traders in both networks regard their ability to think critically about geopolitics as being central to the way they make a profit at the interface of multiple geopolitical projects. This mode of activity distinguishes them from trading communities that are directly associated with one or other geopolitical player in Asia. For such communities, association with a single political entity brings benefits in protection and consular support, but also risks. Turkey's volatile relationships with Russia and China over issues ranging from the Syrian conflict to the status of Uyghur Muslims in Xinjiang have intermittently affected Turkish businesspeople across these contexts. Turkish businesspeople vacated Russia in the aftermath of the downturn in Russian-Turkish ties in the wake of Turkey shooting down a Russian jet in 2015. In 2016, Turkish traders in Yiwu told me that poor relations between Beijing and Ankara had made it difficult for them to acquire Chinese visas. Afghan traders operating in the Eurasian and West Asian corridors, by contrast, thrive in the interstices between geopolitical projects.

Geopolitical dynamics are having a considerable effect on the traders' geographical location and the routes along which they move and transport commodities, as well as capital. Chapters 2 and 3 distinguished between two distinct corridors of connectivity that have been shaped by histories of geopolitical dynamics including those connected to nineteenth-century European empires and their aftermath, the Cold War and the contemporary attempts of China and Russia to promote particular visions of Eurasian connectivity. Yet there is the possibility that commercial networks that have been historically and geographically disconnected will fold into one another. During my time conducting fieldwork, for example, I met a trader in Jeddah who had sent his children to be educated in 
aeronautical engineering in a Ukrainian university and a trader who ran a currency exchange business between Istanbul and Jeddah who had recently expanded his activities to Odessa. Afghan traders develop routes and businesses not in relation to ideologies such as Turkic or Islamic identity but, rather, the pragmatic concerns of trade, commerce and livelihoods. As a result, they are well positioned to continue to author unfolding forms of transregional connectivity that build off but also transcend those of particular geopolitical projects. The Afghan state's ability to benefit from such connections depends on its willingness to recognise the relevance of engaging with mobile communities and networks and the particularity of the routes they forge.

Chapter 4 focuses on a node of particular importance to both of the networks explored in this and previous chapters: Yiwu, a trading city in China in which individuals making up diverse trading networks meet and interact. This will involve a discussion of the ways in which diverse trading networks interact in the city, both with one another and with the city's authorities and policymakers, and an exploration of the ways in which geopolitical processes contribute to the socio-spatial organisation of Yiwu. 